\title{
CIRCULATION OF HUMAN PAPILLOMAVIRUS (HPV) GENOTYPES IN WOMEN FROM CÓRDOBA, ARGENTINA, WITH SQUAMOUS INTRAEPITHELIAL LESIONS
}

\author{
Raul Fernando VENEZUELA, Ana Ximena KIGUEN, Maria Celia FRUTOS \& Cecilia Gabriela CUFFINI
}

\begin{abstract}
SUMMARY
Human papillomavirus (HPV) can induce a wide spectrum of squamous intraepithelial lesions (SIL) of varying severity. The aim of the present study was to establish the frequency of HPV infection and identify the genotypes circulating in women from Córdoba, Argentina, in relation to age and cytology. A total of 186 women, between 18 and 65 years old, with antecedents of SIL, underwent a pelvic examination and had cervical cells collected for cytology and HPV DNA detection. Ninety-six samples $(51.6 \%)$ were positive for HPV detection, and sixty-three (65.6\%) of them showed the presence of at least one HR-HPV. Low- and high-grade SIL showed significant association in patients younger than 35 years of age. We found 18 different genotypes, with a greater presence of HR-HPV. Genotypes 16 and 6 were the most frequent. Seven (7.3\%) multiple infections, $85.7 \%$ of which had at least one HR-HPV, were detected. The detection of a large number of different HPV genotypes is a warning sign. It is thus necessary to strengthen the monitoring of the circulation of high-risk genotypes, currently less prevalent in intraepithelial lesions, as a control measure for the possible impact of the implementation of vaccines against genotypes 16 and 18.
\end{abstract}

KEYWORDS: HPV; Squamous intraepithelial lesions; Cervix; Genotypes, Argentina.

\section{INTRODUCTION}

Human Papillomavirus (HPV) can induce a wide spectrum of squamous intraepithelial lesions of varying severity. The prevalence of HPV genital infection, which is the most common sexually transmitted infection worldwide, depends on the woman's age and the method of detection ${ }^{5}$. Numerous studies have reported that certain types of HPV are the main cause of cervical cancer. More than 40 genotypes have been identified in the anogenital tract. Depending on their association with low/high-grade squamous intraepithelial lesions or invasive carcinomas, they can be grouped into low-risk (LR-HPV), such as HPV 6 and 11, and high-risk HPV (HR-HPV), such as HPV 16, 18, 31, and 33 $3^{18,23}$.

The pathogenesis of cervical cancer begins as a slow process that disrupts the differentiation of the cervical squamous epithelium, causing changes in its structure and physiology ${ }^{35}$.

Cervical cell dysplasia, which is evidenced by alterations in the shape, size and organization of the epithelium, is caused as a result of infection with $\mathrm{HPV}^{20,35}$.

By means of the Bethesda System ${ }^{31}$, these lesions may be classified as: atypical squamous cells of undetermined significance (ASCUS), low-grade squamous intraepithelial lesions (LSIL), high-grade squamous intraepithelial lesions (HSIL) or Squamous Cell Carcinoma (SCC).

The knowledge of HPV genotypes in our female population is important for establishing strategies to prevent SCC and control squamous intraepithelial lesions, including the molecular diagnosis of the virus and vaccination. Thus, considering the recent inclusion of anti-HPV vaccines in the National Vaccination Calendar, the monitoring of circulating genotypes should be sustained over time, since the possible existence of mechanisms of immune pressure would result in a decreased circulation of the genotypes listed in the vaccines and the consequent increase in the frequency of detection of those not included in the formulation.

The goal of the present study was to establish the frequency of HPV infection and identify the genotypes circulating in women in the city of Córdoba, Argentina, in relation to age and cytology.

\section{MATERIALS AND METHODS}

A total of 186 women with antecedents of squamous intraepithelial lesions who attended private clinics and public health centers in Córdoba, Argentina, between May 2008 and May 2010 were invited to participate in a cross-sectional study on cervical HPV infection. At the beginning of the study, participants answered a questionnaire and signed a written consent form, in accordance with the Ethics Committee of the School of 
VENEZUELA, R.F.; KIGUEN, A.X.; FRUTOS, M.C. \& CUFFINI, C.G. - Circulation of human papillomavirus (HPV) genotypes in women from Córdoba, Argentina, with squamous intraepithelial lesions. Rev. Inst. Med. Trop. Sao Paulo, 54(1): 11-6, 2012.

Medical Sciences of the University of Córdoba. Participants were then subjected to a pelvic examination for the collection of cervical cells for cytology and HPV-DNA detection.

The samples were collected in $500 \mu \mathrm{L}$ phosphate-buffered saline (PBS). DNA was extracted using the commercial AccuPrep Genomic DNA Extraction Kit (Bioneer Inc., CA, USA), in accordance with the manufacturer's instructions.

A 450-bp segment, corresponding to the L1 region of the viral genome, was amplified by PCR, using the degenerate primers MY09 and MY11 (Integrated DNA Technology - USA) ${ }^{3}$. The product was detected by electrophoresis in agarose gel at $1.5 \%$ using a U.V. transilluminator. The $\beta$-globin gene was used as a DNA preservation marker ${ }^{12}$. Negative samples were considered inadequate.

HPV-DNA positive samples were typed by Restriction Fragment Length Polymorphism (RFLP) according to BERNARD et al., 1994. Briefly, aliquots of the PCR products obtained using the degenerate consensus primers MY09-MY11, targeting a region of approximately $450 \mathrm{bp}$ in length in the L1 ORF of the viral genome, were mixed with seven different restriction enzymes (Bam HI, Hae III, Dde I, Pst I, Hinf I, $S a u$ III, and $R s a$ I) in separate reactions. The digestion products were separated by electrophoresis in 3\% agarose gel and the pattern obtained compared with published data ${ }^{3}$.

Statistical analysis was carried out with InfoStat version 2011, with a significance level of $5 \%[95 \% \mathrm{CI}]^{17}$.

In order to estimate the probabilities of occurrence, we calculated the frequencies for the different genotypes, ages and cytological characteristics.

Chi-square $(\chi 2)$ tests for independence were conducted to determine the association between different age groups, cytological characteristics,
HPV genotype and risk. At the same time, logistic regressions were performed to determine association between age, type of lesion (LSIL/ HSIL) and genotype. For the latter, we worked with genotypes 6, 11, 16 and 18.

\section{RESULTS}

The age of the patients ranged between 18 and 65 years old (mean age 31.13 years) and the distribution by age was as follows: $<25$ years $(\bar{x} 22.1$ SD 1.79$)=35(18.8 \%), 25-34$ years $(\bar{x} 29.5$ SD 2.76$)=96(51.6)$, $35-44$ years $(\bar{x} 38.9$ SD 2.89$)=28(15.1 \%)$ and $\geq 45$ years $(\bar{x} 48.7$ SD $5.71)=11(5.9 \%)$. Age information was not available for sixteen of the samples $(8.6 \%)$. These samples were thus excluded from the age analysis.

The Papanicolaou smears were stained and interpreted locally by a team of cytopathologists and the results were classified according to the Bethesda System. LSIL was diagnosed in 120 women (64.5\%), HSIL in $42(22.6 \%)$, ASCUS in $16(8.6 \%)$, and SCC in one $(0.5 \%)$. Seven samples $(3.8 \%)$ were normal.

All of the samples showed gene amplification for the beta-globin.

Ninety-six samples $(51.6 \%)$ were positive for HPV detection, and sixty-three $(65.6 \%)$ of them (i.e. $33.9 \%$ of all samples) showed the presence of at least one HR-HPV.

Table 1 shows the detection of HPV (HR-HPV and LR-HPV) in function of age, compared with the cytological classification.

Although the overall analysis did not show predominance of any of the cytological classifications by age group $\left(\chi^{2}=17.9, p=0.3276\right)$, in the analysis of independence between the age group and the type of lesion (HSIL and LSIL), we found a significant association with women under 35 years $\left(\chi^{2}=4.9, p=0.026 \mathrm{OR}=0.30,0.10\right.$ to 0.87$)$.

Table 1

Age distribution and cytology

\begin{tabular}{|c|c|c|c|c|c|c|c|c|c|c|c|c|c|c|c|c|c|c|}
\hline & \multicolumn{3}{|c|}{$<25$} & \multicolumn{3}{|c|}{$25-34$} & \multicolumn{3}{|c|}{$35-44$} & \multicolumn{3}{|c|}{$\geq 45$} & \multicolumn{3}{|c|}{ WITHOUT AGE } & \multicolumn{3}{|c|}{ TOTAL } \\
\hline & $\mathrm{n}^{\circ}$ & Pos & $\%$ & $\mathrm{n}^{\mathrm{o}}$ & Pos & $\%$ & $\mathrm{n}^{\circ}$ & Pos & $\%$ & $\mathrm{n}^{\circ}$ & Pos & $\%$ & $\mathrm{n}^{\mathrm{o}}$ & Pos & $\%$ & $\mathrm{n}^{\mathrm{o}}$ & Pos & $\%$ \\
\hline ASCUS & 2 & 2 & $(100.0)$ & 7 & 3 & $(42.8)$ & 3 & - & - & 1 & 1 & $(100.0)$ & 3 & 1 & $(33.3)$ & 16 & 7 & $(43.7)$ \\
\hline HR-HPV & & 2 & (100.0) & & - & - & & - & - & & - & - & & 1 & (100.0) & & 3 & $(42.9)$ \\
\hline LR-HPV & & - & - & & 3 & $(100.0)$ & & - & - & & 1 & $(100.0)$ & & - & - & & 4 & $(57.1)$ \\
\hline LSIL & 23 & 14 & $(60.8)$ & 57 & 26 & $(45.6)$ & 21 & 8 & $(38.1)$ & 8 & 5 & $(62.5)$ & 11 & 4 & $(36.4)$ & 120 & 57 & $(47.5)$ \\
\hline HR-HPV & & 11 & (78.6) & & 17 & $(65.4)$ & & 2 & $(25.0)$ & & 1 & $(20.0)$ & & 2 & $(50.0)$ & & 33 & $(57.9)$ \\
\hline LR-HPV & & 3 & $(21.4)$ & & 9 & (34.6) & & 6 & $(75.0)$ & & 4 & $(80.0)$ & & 2 & $(50.0)$ & & 24 & $(42.1)$ \\
\hline HSIL & 7 & 4 & $(57.1)$ & 30 & 23 & (76.6) & 3 & 2 & $(66.7)$ & 1 & 1 & (100.0) & 1 & - & - & 42 & 30 & (71.4) \\
\hline HR-HPV & & 2 & $(50.0)$ & & 21 & (91.3) & & 2 & (100.0) & & 1 & (100.0) & & - & - & & 26 & (86.7) \\
\hline LR-HPV & & 2 & $(50.0)$ & & 2 & $(8.7)$ & & - & - & & - & - & & - & - & & 4 & (13.3) \\
\hline TOTAL & 35 & 21 & $(60.0)$ & 96 & 52 & $(54.2)$ & 28 & 10 & $(35.7)$ & 11 & 7 & (63.6) & 16 & 6 & $(37.5)$ & 186 & 96 & (51.6) \\
\hline HR-HPV & & 16 & $(76.2)$ & & 38 & (73.1) & & 4 & $(40.0)$ & & 2 & (28.6) & & 3 & $(50.0)$ & & 63 & (65.6) \\
\hline LR-HPV & & 5 & (23.8) & & 14 & (26.9) & & 6 & $(60.0)$ & & 5 & (71.4) & & 3 & $(50.0)$ & & 33 & $(34.4)$ \\
\hline
\end{tabular}

The multiple infections that had at least one HR-HPV were considered to be HR-HPV because of their clinical importance. Data not included in the table: Normal, 2 patients, <25, 2 patients, 25-34, 1 patient, 35-44, 1 patient, $\geq 45$ and Without Age, 1 that was LR-HPV. SCC: 1 patient $<25$ HR-HPV. 


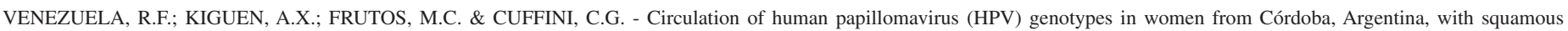
intraepithelial lesions. Rev. Inst. Med. Trop. Sao Paulo, 54(1): 11-6, 2012.

The HSIL lesion type had the highest detection of HPV (71.4\%) and frequency of HR-HPV (86.7\%). However, the distribution of HR-HPV did not show a statistically significant association with the type of lesion $\left(\chi^{2}=2.7, p=0.0995 \mathrm{OR}=0.43,0.16,1.16\right)$. In spite of this, except for the group $<25$ years old, the detection rate of HR-HPV in HSIL was higher than $90 \%$.

In addition, HPV detection exceeded $50 \%$ in all age groups, except for the 35-44 year old group; in the group $<25$ years old we detected the largest percentage of HR-HPV (76.2\%), most of which (78.6\%) were detected in LSIL.

Table 2 shows the distribution of genotypes according to the cytological classification. The most prevalent genotypes were 16 and 6 . Together, these two genotypes reached $50 \%$ of the total (52/104, including multiple infections). Both were identified in all cytological classifications, except for genotype 6 in SCC and 16 in normal.

Genotype 16 was the most prevalent in SCC and HSIL, whereas genotype 6 was the most prevalent in normal samples as well as in ASCUS and LSIL.

The second most prevalent LR-HPV was genotype $11(8.3 \%)$, which was detected only in ASCUS and LSIL, whereas the second most prevalent HR-HPV were genotypes 18, 52 and 58 (6.2\% each), which were found in LSIL and HSIL, with a higher percentage in the latter.

The four most frequent genotypes in HSIL were 16, 52, 18 and 58, whereas the most frequent in LSIL were 6, 16, 11 and 31.

In the logistic regression analysis for lesion type, age and genotype, HPV 16, 11 and 18 were present in all age groups and lesion types, without statistical association. In contrast, genotype 6 showed association with LSIL $(\beta=-1.65, p$ value $=0.0417, \mathrm{OR}=0.19,0.04-0.94)$, but such association was not observed with the different ages (Table 3).

RFLP analysis detected the presence of seven (7.3\%) multiple infections, $85.7 \%$ of which had at least one HR-HPV, being genotype 16 the most frequent one. The distribution of these infections according to the lesion was: LSIL 57.1\%, HSIL 28.6\% and ASCUS 14.3\%, but the frequencies of multiple infections vs. lesions did not show significant differences $\left(\chi^{2}=3.75, p\right.$ value $\left.=0.4409\right)$.

Six of these multiple infections $(85.7 \%)$ were observed in women
Table 2

Distribution of genotypes vs cytology classification

\begin{tabular}{|c|c|c|c|c|c|c|}
\hline Genotype & Total & Normal & ASCUS & LSIL & HSIL & SCC \\
\hline 16 & $25(26.0)$ & - & $1(14.3)$ & $14(24.6)$ & $9(30.0)$ & $1(100.0)$ \\
\hline 6 & 21 (21.9) & $1(100.0)$ & $3(42.8)$ & $15(26.3)$ & $2(6.7)$ & - \\
\hline 11 & $8(8.3)$ & - & $1(14.3)$ & $7(12.3)$ & - & - \\
\hline 18 & $6(6.2)$ & - & - & $2(3.5)$ & $4(13.3)$ & - \\
\hline 58 & $6(6.2)$ & - & - & $2(3.5)$ & $4(13.3)$ & - \\
\hline 52 & $6(6.2)$ & - & - & $1(1.7)$ & $5(16.7)$ & - \\
\hline 31 & $5(5.2)$ & - & - & $3(5.3)$ & $2(6.7)$ & - \\
\hline 45 & $3(3.1)$ & - & $1(14.3)$ & $2(3.5)$ & - & - \\
\hline 33 & $2(2.3)$ & - & - & $1(1.7)$ & $1(3.3)$ & - \\
\hline 35 & $2(2.3)$ & - & - & $2(3.5)$ & - & - \\
\hline $59+61$ & $2(2.3)$ & - & - & $1(1.7)$ & $1(3.3)$ & - \\
\hline 51 & $1(1.0)$ & - & - & $1(1.7)$ & - & - \\
\hline 53 & $1(1.0)$ & - & - & - & $1(3.3)$ & - \\
\hline 59 & $1(1.0)$ & - & - & $1(1.7)$ & - & - \\
\hline 61 & $1(1.0)$ & - & - & $1(1.7)$ & - & - \\
\hline 62 & $1(1.0)$ & - & - & $1(1.7)$ & - & - \\
\hline $16+56$ & $1(1.0)$ & - & - & $1(1.7)$ & - & - \\
\hline $16+6$ & $1(1.0)$ & - & - & $1(1.7)$ & - & - \\
\hline $16+61+62$ & $1(1.0)$ & - & $1(14.3)$ & - & - & - \\
\hline $16+64$ & $1(1.0)$ & - & - & $1(1.7)$ & - & - \\
\hline $6+54$ & $1(1.0)$ & - & - & - & $1(3.3)$ & - \\
\hline TOTAL & $96(100.0)$ & $1(1.0)$ & $7(7.3)$ & $57(59.4)$ & $30(31.3)$ & $1(1.0)$ \\
\hline
\end{tabular}

under 35 years old, more frequently in the 25-34 year old group (57.1\%) (data not shown).

Figure 1 shows a comparison between the detection of genotypes included in the anti-HPV vaccine and of those not included in the formulation. The goodness-of-fit test shows statistically significant differences between pairs of columns: HR-HPV 16 and 18 vs. HR-HPV genotypes other than 16 and $18\left(\chi^{2}=6.00 ; p\right.$ value $\left.=0.0143\right)$, LR-HPV 6 and 11 vs. LR-HPV genotypes other than 6 and $11\left(\chi^{2}=15.04 ; p\right.$ value

Table 3

Logistic regression analysis for lesion type, age and genotype

\begin{tabular}{|c|c|c|c|c|c|c|c|c|c|c|}
\hline \multirow{2}{*}{ GENOTYPE } & \multicolumn{5}{|c|}{ Lesion (HSIL-LSIL) } & \multicolumn{5}{|c|}{ Age } \\
\hline & $\beta$ & $p(<0.05)$ & $\mathrm{OR}$ & $95 \% \mathrm{CI}$ & AIC & $\beta$ & $p(<0.05)$ & OR & $95 \% \mathrm{CI}$ & AIC \\
\hline 6 & -1.65 & 0.0417 & 0.19 & $0.04-0.94$ & 124.98 & 0.01 & 0.8082 & 0.99 & $0.92-1.07$ & 131.04 \\
\hline 11 & 0.001 & 0.5534 & 1.00 & $1.00-1.00$ & 125.07 & 0.01 & 0.8549 & 0.99 & $0.93-1.07$ & 131.38 \\
\hline 16 & 0.28 & 0.5520 & 1.32 & $0.49-3.61$ & 129.75 & -0.01 & 0.8121 & 1.01 & $0.94-1.08$ & 135.79 \\
\hline 18 & 1.36 & 0.1318 & 3.91 & $0.66-23.07$ & 126.00 & -0.009 & 0.9701 & 1.00 & $0.94-1.07$ & 132.49 \\
\hline
\end{tabular}

AIC: Akaike's Information Criterion 


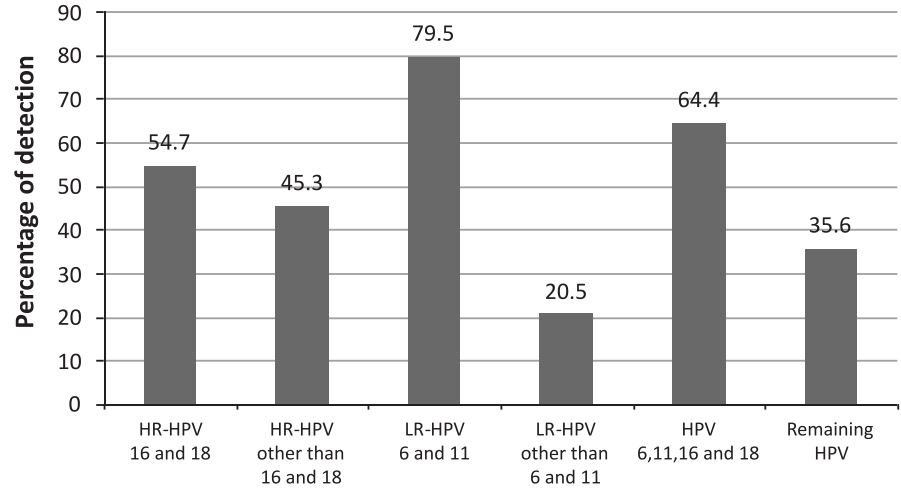

Data obtained from the HPV genotyping of patients from the current study.

Fig. 1 - Genotypes included in vaccines vs not included in vaccines.

$<0.001)$ and $6,11,16$ and 18 vs. remaining $\operatorname{HPV}\left(\chi^{2}=12.04 ; p\right.$ value $<0.001)$.

\section{DISCUSSION}

In the present study, the percentage of HPV detection (51.6\%) was similar to that described in the region (between $41 \%$ and 64\%). Similarly, HR-HPV detection $(65 \%)$ was within the range previously reported $(30-73 \%)$ for the same population using the same detection method ${ }^{13,29}$.

Notably, as also observed in studies carried out in Concordia, Argentina, the frequency of HR-HPV decreases as age increases, possibly associated with the development of immunity against these genotypes ${ }^{22}$.

Our work highlights the importance of HPV screening in assessing the prognosis, control of the lesion, and implementation of the treatment ${ }^{11}$, since a high percentage $(57.9 \%)$ of HR-HPV was detected in LSIL, $13.3 \%$ of HSIL was positive for LR-HPV and $28.6 \%$ of HSIL was negative for HPV.

Although the high percentage of HR-HPV in LSIL coincides with the results of a meta-analysis carried out in different regions of the world ${ }^{8}$, there is no evidence of a statistically significant difference, thus suggesting that both LR-HPV and HR-HPV can be found in this lesion.

The lack of agreement in HPV detection in samples with normal classification may be because in our work the number of patients who had normal smears was very low.

Although we detected 18 different genotypes, most of which were HR-HPV, the distribution of genotypes in our study was polarized between HPV 6 and 16, since the frequencies of these genotypes were respectively two and three times higher than the remaining ones (Table 2).

The higher frequency of detection of genotype 16 is in agreement with that found in previous reports carried out in the region and others carried out in the Iberian Peninsula, with some variations in the detection rate of the remaining genotypes ${ }^{2,4,6,9,22}$.

We found no statistical association between HPV 16 and the type of lesion (by logistic regression analysis, $\beta$ : $0.28, p$ : 0.5820 ). We conclude that, in agreement with what was previously reported ${ }^{15,33}$, HPV 16 can be found in HSIL and LSIL. However, in our population, genotype 16 was found mostly in HSIL.

In agreement with the findings of other authors ${ }^{21}$, HR-HPV 16, 18, 52 and 58 were most frequently detected in HSIL. We also found that the only LR-HPV genotypes found in HSIL were 6 and 54, the latter of which was found in multiple infections with HPV 6.

Among the genotypes not present in the development of vaccines, the most frequently detected were HPV 52 and HPV 58 (Table 2). These were more common in HSIL and observed in the 25-34 age group (data not shown).

Some prevalence studies have indicated that the DNA of HPV 52 is present in approximately $2 \%$ of all cases of cervical squamous intraepithelial lesions ${ }^{28,29}$ and that the presence of HPV 58 for these lesions ranges from $6 \%$ to $20 \%$, which is the range within which these genotypes were detected in our work ${ }^{13,24,25,26}$.

The detection of multiple infections was lower than that in other regions, and at least one HR-HPV was detected in most multiple infections ${ }^{22,29}$. Some studies have reported a close association between multiple infections and the increase in the severity of the lesion ${ }^{10,19}$. However, in agreement with other studies, most of the multiple infections in our work were detected in LSIL $(57.1 \%)$. This could be due to the fact that in high-grade lesions, the viral DNA is integrated into the host's genome, which leads to partial loss of the region of the L1 gene, to which the amplification by the MY09/11 primer set is directed ${ }^{14,32}$.

Another interesting aspect of the presence of these infections is the generation of an environment that favors potential recombination, which may have a major impact on pharmacogenomics and primary prevention with the implementation of existing vaccines ${ }^{1}$.

It is noteworthy that the variety of HR-HPV is about twice that of LR-HPV (11 vs. 7) and, as shown in Fig. 1, although immunization with existing vaccines would cover more than $50 \%$ of infections, a high percentage $(45.3 \%)$ of HR-HPV infections would not be prevented by these vaccines. Although the cross-protection data are encouraging ${ }^{16,30}$, the titers of the neutralizing antibodies for the genotypes not included in the formulation are about ten times lower than those for the genotypes that are included. This generates uncertainty about whether they will disappear more rapidly than the specific antibodies. It has also been reported that the protection against HPV 52 and HPV 58 (two of the four most frequent HR-HPV in our study) is not significant. These data have led some authors to infer that the cross-protection seems to be limited ${ }^{27,30}$.

The distribution of HPV among different populations is not homogeneous, and the interaction of human relations leads to viral dynamics that could alter the relative risk of each lesion in the population, especially when prevalence of HR-HPV is high $^{34}$.

The information provided in the present study, which is the first to be carried out in Córdoba, Argentina, is important for the prevention of $\mathrm{HPV}$, and highlights the importance of routine gynecological controls in women younger than 35 years of age, since this age group was found to be associated with LSIL and HSIL. Another important finding is that 
VENEZUELA, R.F.; KIGUEN, A.X.; FRUTOS, M.C. \& CUFFINI, C.G. - Circulation of human papillomavirus (HPV) genotypes in women from Córdoba, Argentina, with squamous intraepithelial lesions. Rev. Inst. Med. Trop. Sao Paulo, 54(1): 11-6, 2012.

HR-HPV can be detected in all lesion types and age groups, with the aggravating circumstance that genotype 16 was found in a high percentage of LSIL, thus demonstrating the importance of virological diagnosis and preventive vaccination against this particular genotype.

\section{RESUMEN}

\section{Circulación de genotipos de virus papiloma humano (VPH) en mujeres con lesiones intrepiteliales escamosas de Córdoba, Argentina}

El papilomavirus humano (human papilloma, HPV) induce un amplio espectro de lesiones intraepiteliales escamosas (SIL) de variada severidad.

Objetivo: conocer la frecuencia de infección por HPV y determinar los genotipos circulantes en mujeres de la ciudad de Córdoba, Argentina, en relación con la edad y la citología. Se realizó citología y detección de ADN-HPV en células cervicales de 186 mujeres de 18 a 65 años con antecedentes de SIL. Noventa y seis $(51.6 \%)$ fueron positivas para la detección del HPV, de las cuales, en 63 (65.6\%) se detectó la presencia de al menos, un HPV de Alto Riesgo (HR-HPV). Las SIL de alto grado (HSIL) y de bajo grado (LSIL) se asociaron a pacientes menores de 35 años. Se hallaron 18 genotipos diferentes, con mayor presencia de HR-HPV. HPV 16 y 6 fueron más frecuentes y se detectaron 7 (7.3\%) infecciones múltiples, $85.7 \%$ de éstas presentaron al menos un HR-HPV. La detección de un alto número de diferentes genotipos es una señal de alerta. Por tanto, es necesario fortalecer la vigilancia de los HR-HPV, actualmente menos frecuentes en las SIL, como medida de control del impacto que tendrá la implementación de las vacunas contra HPV 16 y 18.

\section{ACKNOWLEDGMENT}

This work was supported by grants from the Ministerio de Ciencia y Tecnología (MINCyT) PIO 170/2011.

\section{REFERENCES}

1. Angulo M, Carvajal-Rodríguez A. Evidence of recombination within human alphapapillomavirus. Virol J. 2007;4:33

2. Ayres AR, Silva GA. Cervical HPV infection in Brazil: systematic review. Rev Saude Publica. 2010;44:963-74.

3. Bernard HU, Chan SY, Manos MM, Ong CK, Villa LL, Delius H, et al. Identification and assessment of known and novel human papillomaviruses by polymerase chain reaction amplification, restriction fragment length polymorphisms, nucleotide sequence, and phylogenetic algorithms. J Infect Dis. 1994;170:1077-85.

4. Bosch FX, Burchell AN, Schiffman M, Giuliano AR, De Sanjose S, Bruni L, et al. Epidemiology and natural history of human papillomavirus infections and typespecific implications in cervical neoplasia. Vaccine. 2008;26(Suppl 10):K1-16.

5. Bosch FX, Lorincz A, Muñoz N, Meijer CJ, Shah KV. The causal relation between human papillomavirus and cervical cancer. J Clin Pathol. 2002; 55:244-65.

6. Camargo M, Soto-De Leon SC, Sanchez R, Perez-Prados A, Patarroyo ME, Patarroyo MA. Frequency of human papillomavirus infection, coinfection, and association with different risk factors in Colombia. Ann Epidemiol. 2011;21:204-13.

7. Chang DY, Chen RJ, Lee SC, Huang SC. Prevalence of single and multiple infection with human papillomaviruses in various grades of cervical neoplasia. J Med Microbiol. 1997;46:54-60.
8. Clifford GM, Rana RK, Franceschi S, Smith JS, Gough G, Pimenta JM. Human papillomavirus genotype distribution in low-grade cervical lesion: comparison by geographic region and with cervical cancer. Cancer Epidemiol Biomarkers Prev. 2005; 14:1157-64.

9. Cobo F, Concha A, Ortiz M. Human papillomavirus (HPV) type distribution in females with abnormal cervical cytology. A correlation with histological study. Open Virol J. 2009;3:60-6.

10. Cuschieri KS, Cubie HA, Whitley MW, Seagar AL, Arends MJ, Moore C, et al. Multiple high risk HPV infections are common in cervical neoplasia and young women in a cervical screening population. J Clin Pathol. 2004; 57: 68-72.

11. De La Fuente J, Zapardiel I, Benavides P. Patología tumoral benigna del cérvix y lesiones cervicales intraepiteliales. In: Bajo Arenas JM, Lailla Vicens JM, Xercavins Montosa J, editores. Fundamentos de Ginecología. Buenos Aires: Editorial Médica Panamericana; 2009. p. 373-380.

12. De Roda Husman AM, Walboomers JM, Van Den Brule AJ, Meijer CJ, Snijders PJ. The use of general primers GP5 and GP6 elongated at their 39 ends with adjacent highly conserved sequences improves human papillomavirus detection by PCR. J Gen Virol. 1995;76:1057-62.

13. Deluca GD, Lucero RH, Martin De Civetta MT, Vicente L, De Gorodner OL, Schelover $\mathrm{E}$, et al. Human papillomavirus genotypes in women with cervical cytological abnormalities from an area with high incidence of cervical cancer. Rev Inst Med Trop Sao Paulo. 2004;46:9-12.

14. Depuydt CE, Boulet GA, Horvath CA, Benoy IH, Vereecken AJ, Bogers JJ. Comparison of MY09/11 consensus PCR and type-specific PCRs in the detection of oncogenic HPV types. J Cell Mol Med. 2007;11:881-91.

15. Gudleviciene Z, Sepetiene A, Didziapetriene J, Valuckas KP, Smailyte G, Drasutiene G, et al. Prevalence of human papillomavirus types in cervical intraepithelial lesions. Medicina (Kaunas). 2010;46:616-23.

16. Harper DM, Franco EL, Wheeler CM, Moscicki AB, Romanowski B, Roteli- Martins CM, et al. Sustained efficacy up to 4.5 years of a bivalent L1 virus-like particle vaccine against human papillomavirus types 16 and 18: follow-up from a randomised control trial. Lancet. 2006;367(9518):1247-55.

17. InfoStat [computer program] versión 2011. Grupo InfoStat, FCA, Universidad Nacional de Córdoba, Argentina. Available from: http://www.infostat.com.ar.

18. International Agency for Research on Cancer (I.A.R.C). Working Group on the evaluation of carcinogenic risks to humans. Human papillomaviruses. Lyon: I.A.R.C; 1995. (I.A.R.C Monographs on the evaluation of carcinogenic risks to humans; v. 64, p. 277-282).

19. Javanbakht M, Gorbach PM, Amani B, Walker S, Cranston RD, Datta SD, et al. Concurrency, sex partner risk, and high-risk human papillomavirus infection among African American, Asian, and Hispanic women. Sex Transm Dis. 2010;37:68-74.

20. Jenkins D. Histopathology and cytopathology of cervical cancer. Dis Markers. 2007;23:199-212.

21. López MJ, Ili GCG, Brebi MP, García MP, Capurro VI, Guzmán GP, et al. Detección y tipificación de virus papiloma humano en lesions preneoplásicas de cuello uterino. Rev Med Chile. 2010; 138:1343-50.

22. Matos E, Loria D, Amestoy GM, Herrera L, Prince MA, Moreno J, et al. Prevalence of human papillomavirus infection among women in Concordia, Argentina: a populationbased study. Sex Transm Dis. 2003;30:593-9.

23. Muñoz N, Bosch FX, Shah KV, Meheus A, editors. The epidemiology of cervical cancer and human papillomavirus. Lyon: International Agency for Research on Cancer; 1992. (I.A.R.C. Scientific publication; No. 119). 
VENEZUELA, R.F.; KIGUEN, A.X.; FRUTOS, M.C. \& CUFFINI, C.G. - Circulation of human papillomavirus (HPV) genotypes in women from Córdoba, Argentina, with squamous intraepithelial lesions. Rev. Inst. Med. Trop. Sao Paulo, 54(1): 11-6, 2012.

24. Oliveira-Silva M, Lordello CX, Zardo LM, Bonvicino CR, Moreira MA. Human papillomavirus in Brazilian women with and without cervical lesions. Virol J. $2011 ; 8: 4$.

25. Pitta DR, Sarian LO, Campos EA, Rabelo-Santos SH, Syrjänen K, Derchain SF. Phylogenetic classification of human papillomavirus genotypes in high-grade cervical intraepithelial neoplasia in women from a densely populated Brazilian urban region. Sao Paulo Med J. 2009;127:122-7.

26. Salih MM, Safi ME, Hart K, Tobi K, Adam I. Genotypes of human papilloma virus in Sudanese women with cervical pathology. Infect Agent Cancer. 2010;5:26.

27. Schiller JT, Castellsagué X, Villa LL, Hildesheim A. An update of prophylactic human papillomavirus L1 virus-like particle vaccine clinical trial results. Vaccine. 2008;26(Suppl 10):K53-61.

28. Shimoda K, Lorincz AT, Temple GF, Lancaster WD. Human papillomavirus type 52: a new virus associated with cervical neoplasia. J Gen Virol. 1988;69(Pt 11):2925-8.

29. Sijvarger CC, González JV, Prieto A, Messmer AG, Mallimaci MC, Alonio VL, et al. Epidemiología de la infección cervical por virus papiloma humano en Ushuaia, Argentina. Rev Argent Microbiol. 2006;38:19-24.

30. Smith JF, Brownlow M, Brown M, Kowalski R, Esser MT, Ruiz W, et al. Antibodies from women immunized with Gardasil cross-neutralize HPV 45 pseudovirions. Hum Vaccin. 2007;3:109-15.
31. Solomon D, Davey D, Kurman R, Moriarty A, O'Connor D, Prey M, et al. The 2001 Bethesda System: terminology for reporting results of cervical cytology. JAMA. 2002;287:2114-9.

32. Tate JE, Yang YC, Shen J, Mclachlin CM, Sheets EE, Crum CP. A comparison of early (E7) and late (L1) primer-mediated amplification of papillomaviral DNA in cervical neoplasia. Mol Cell Probes. 1996;10:347-51.

33. Tonon SA, Picconi MA, Zinovich JB, Liotta DJ, Bos PD, Galuppo JA, et al. Human papillomavirus cervical infection and associated risk factors in a region of Argentina with a high incidence of cervical carcinoma. Infect Dis Obstet Gynecol. 1999;7:23743.

34. Tonon SA, Picconi MA, Zinovich JB, Nardari W, Mampaey M, Galuppo JA, et al Prevalencia de la infección cervical por virus papiloma humano (HPV) en población caucásica y guarani, residente en la provincia de Misiones, Argentina. Rev Argent Microbiol. 2003;35:205-13.

35. Woodman CB, Collins SI, Young LS. The natural history of cervical HPV infection: unresolved issues. Nat Rev Cancer. 2007;7:11-22.

Received: 5 August 2011

Accepted: 10 November 2011 